\title{
DESCRIPTION AND DISCRIMINATION OF FRESHNESS AND BIOMETRIC QUALITIES OF THREE DIFFERENT FISHES: GRASS CARP, PACU, AND CATFISH
}

\author{
B. Nogueira, A.C. Belusso, L.S. Breda, T. Oldoni and M.L. Mitterer-Daltó́* \\ Federal Technological University of Paraná, 85503-390 Pato Branco, Paraná. Brazil
}

(Received: 15 November 2018; accepted: 15 December 2018)

\begin{abstract}
The goal of this work was to wade into the freshness quality and biometric evaluation, by means of distinct statistical descriptive methods, on three fresh catch species of fish, as well as to evaluate the discriminant potential of the variables targeted in the study. The species grass carp (Ctenopharyngodon idella), pacu (Piaractus mesopotamicus), and catfish (Ictalurus punctatus) were caught at a rural property located in the city of Pato Branco, PR, Brazil. These fresh catch were weighed, measured, eviscerated, and cut into fillets for acquisition of biometric parameters. Freshness was judged by the analysis of the total volatile basic nitrogen (TVB-N) value and $\mathrm{pH}$. The comparison between means and medians showed symmetries for biometric measures. Correlations between body measures and fillet yield showed a weak relation regardless of the species analysed, wherein the best equation for predictions was obtained by relating total weight to the fillet's weight. The biometric variables were the best discriminants for the species.
\end{abstract}

Keywords: biometrics, box plot, discriminant analysis, mean, median, fish

Brazilians are characterized by low fish consumption. Previous research works conferred proof of the low consumption of fresh catch in the Southern regions of Brazil (MitTERERDALtoÉ et al., 2013a, b). The South-western region of Paraná/Brazil shows a real production potential of fresh catch through fish farming. Local authorities target the increase of the production, although for such, they rely on the true interest of the small rural growers, who in turn need incentives. There are several hurdles to the development of the region's fish farming chain, among them are lack of know-how and lack of production incentives of other species of fish for the time period between harvests of tilapias (Pseudocrenilabrinae), a fish that is highly appreciated among producers and has a prominent market value. The practice of not farming these alternative species is due to the lack of incentives and know-how on the part of the small rural farmers. Among these species are grass carp, catfish, and pacu.

Therefore, the study of the freshness and biometric features of these species becomes paramount, since one of the strategies pointed out as stimulus to the increase in production and consumption of the fresh catch fishes in the region is the development of products derived from this food item. The characterization of the biometric properties and freshness of this raw material not only provides for the knowledge of the quality value of fresh catch, but is also important for technological processes, such as the phases of processing or sensory quality and stability of the end product (JABEEN \& CHAUDHRY, 2011).

In this sense, the goal of the work was to take on the freshness and biometric assessment, in light of distinct statistical methods on three species of fresh catch fishes with the potential for farming in the Southwest region of Paraná, as well as to evaluate the discriminant capability of the variables under study by means of multivariate statistical techniques.

\footnotetext{
* To whom correspondence should be addressed.

E-mail: marinadaltoe@utfpr.edu.br
} 


\section{Materials and methods}

\subsection{Samples of fresh catch and biometric evaluation}

For each fish species six specimens were captured at a rural property, specialized in fish farming, located in the city of Pato Branco, PR. All species were fed with ration (BioBase line Bioaqua) containing $40 \mathrm{~g} \mathrm{~kg}^{-1}$ protein. Grass carp beyond ration received also elephant grass pasture (Pennisetum purpureum). After the fish were captured, they were measured from the top of the head to the tail fin, weighed, eviscerated, cut into fillets, placed inside a cool box with ice, and transported to the Laboratory of Food Technology of the Federal Technological University of Paraná for analyses.

\subsection{Evaluation of the fish-catch's freshness}

The physiochemical alterations of the three species of fresh catch were evaluated by measurement of total volatile basic nitrogen (TVB-N) and pH, according to BRASIL (1981). For analyses, flesh samples $(300 \mathrm{~g})$ were obtained by cutting slices from the dorsal, ventral, and tail area, then the samples were homogenized in a food processor (Mondial Premium). TVB-N was determined by distillation of the sample alkalified with $\mathrm{MgO}(2 \mathrm{~g})$ in a nitrogen distillation apparatus (TECNAL $\left.{ }^{\circledR}\right)$. For that the protein fraction was separated by homogenizing the fish muscle with $20 \%$ trichloroacetic acid. The $\mathrm{pH}$ of the fishes was measured by homogenizing $25 \mathrm{~g}$ of fish muscle with $5 \mathrm{ml}$ of water and using a bench top equipment $($ TECNAL $\AA$ ) with the electrode (Mettler Toledo) coupled to a digital meter.

\subsection{Statistical analyses}

The data were analysed by means of the descriptive methods: mean, standard deviation, variance analysis, and Tukey's comparison test of means. The global outcomes were also shown by box plot (NAES et al., 2010) through the values of the median. So as to better understand the differences among the fishes, a multivariate statistical analysis of canonical discriminant was employed (GonzÁLEZ et al., 2011). The data were analysed with the software Statistica 12.7 .

\section{Results and discussion}

\subsection{Freshness and biometric description of the three species of fresh catch fishes}

The raw materials were characterized for freshness, and the average values of the parameters are expressed in Table 1. Intending to visualize the variation of the results more clearly, these same parameters were presented in the form of box graphic (box plot) (Fig. 1). The length of the box represents $50 \%$ of the central values of y (response variable), and the point shows the median. The lines reveal the range non-outlier/extreme ends. The medians have advantage over the averages, for they are more robust, the outliers do not have such an effect on the median as on average, and are better adjusted to situations with fewer observations, being indicative, therefore, of the central tendency of the dataset (NAES et al., 2010; Lem et al., 2013).

The analysis of freshness for fresh catch fishes is a quality parameter of the food in itself, the chemical methods most often employed are TVB-N and $\mathrm{pH}$ determinations (Briones-Labarca et al., 2012; FernándeZ-Segovia et al., 2012). 


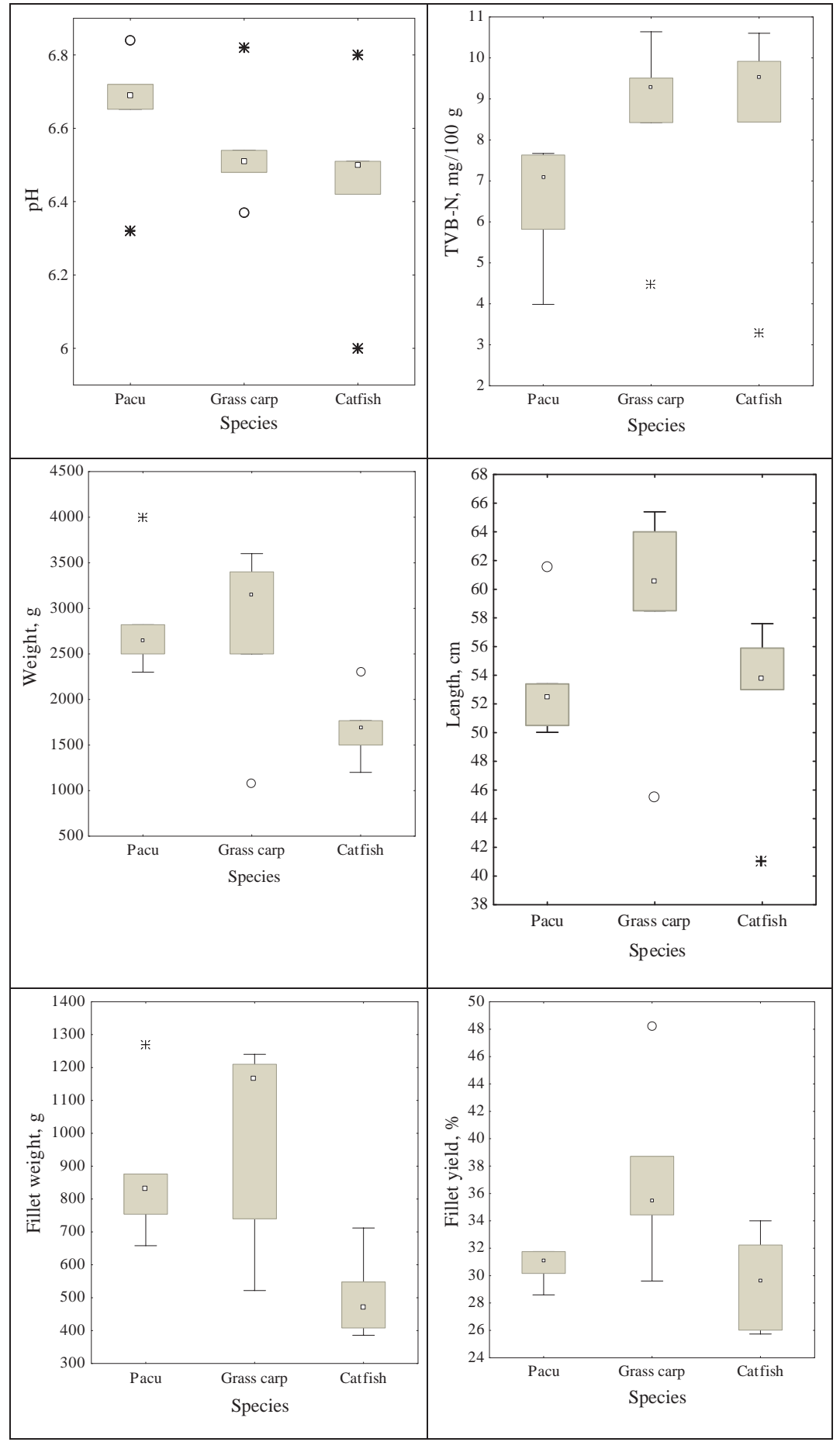

Fig. 1. Box plot of freshness and biometric characterization of the three studied species. $\square$ : Median; : the length of the box represents $50 \%$ of the central values of y or $25-75 \%$ of the observations; I: non-outlier range; ${ }^{\circ}$ : outlier (extremely high and low values); *: extremes 
Table 1. Average values and standard deviation of freshness of fillet of the three species of fresh fish

\begin{tabular}{lcc}
\hline Species & TVB-N $(\mathrm{mg} / 100 \mathrm{~g})$ & $\mathrm{pH}$ \\
\hline Pacu & $6.5 \pm 1.5^{\mathrm{a}}$ & $6.6 \pm 0.2^{\mathrm{a}}$ \\
Carp & $8.6 \pm 2.1^{\mathrm{a}}$ & $6.5 \pm 0.1^{\mathrm{a}}$ \\
Catfish & $8.5 \pm 2.7^{\mathrm{a}}$ & $6.4 \pm 0.2^{\mathrm{a}}$ \\
\hline
\end{tabular}

Averages \pm standard deviation are of three parallel measurements. Values followed by the same letters in the same column do not present a significant difference by Tukey's test $(\mathrm{P} \leq 0.05)$. $\mathrm{N}=6$

The values found for TVB-N and $\mathrm{pH}$ in the three species of fresh fishes are within the tolerance limits required by Brazilian legislation, which are $30 \mathrm{mg} / 100 \mathrm{~g}$ for TVB-N and a maximum $\mathrm{pH}$ of 6.8 (BRASIL, 1981). The average values for $\mathrm{pH}$ and TVB-N among the species did not show significant differences ( $\mathrm{P} \geq 0.05)$. According to Huss (1995), concentrations of TVB-N in fresh catch are in the range from 5 to $20 \mathrm{mg} / 100 \mathrm{~g}$. In this study, the values varied from 3.3 to $10.6 \mathrm{mg} / 100 \mathrm{~g}$ (Fig. 1), which reflect the quality of the raw material used.

More than just reflecting the freshness of the raw material, these low values of TVB-N and $\mathrm{pH}$ indicate the potentiality of these species, since lower values of $\mathrm{pH}$ and TVB-N are indicative of proteins with functional properties preserved beside decelerated lipid oxidation (SoARES et al., 2012).

It is worth noting, that asymmetry was verified among the results of average and medians for the values of measurement of freshness quality. The median is a robust measurement, for it is not affected by the extreme values as the arithmetic average. The average is influenced by the extreme values of the distribution and must only be employed in symmetric distributions or in slightly asymmetric ones (FEIJOO, 2010).

Proceeding with the biometric characterization, it was verified again the importance of the data analysis by box plot, where the asymmetry was verified between means and medians, highlighting the variable 'total weight'.

Table 2 shows the average values concerning biometric characterization. In relation to the total weight of the three species, the existence of a significant difference is verified $(\mathrm{P} \leq 0.05)$ between catfish $(1694.7 \mathrm{~g})$ and grass carp (2813.7 g), and catfish and pacu (2820.0 $\mathrm{g})$. There is a different trend when analysing the values by box plot. With medians with values of $2650 \mathrm{~g}$ for pacu and $3150 \mathrm{~g}$ for grass carp, it is feasible to verify a difference of up to half a kilogram between the two species, which by the values of the averages differ in only $7 \mathrm{~g}$. Such difference is foremost and meaningful when the focus is on derivatives-processing of fresh catch in the industrial scenario (INTARAK et al., 2015).

Table 2. Biometric characterization of the three species of fresh catch

\begin{tabular}{lcccc}
\hline Species & Total weight $(\mathrm{g})$ & Total length $(\mathrm{cm})$ & Weight of fillet $(\mathrm{g})$ & Fillet yield $(\%)$ \\
\hline Pacu & $2820.0 \pm 611.2^{\mathrm{a}}$ & $53.4 \pm 4.2^{\mathrm{a}}$ & $870.3 \pm 211.7^{\mathrm{a}}$ & $30.7 \pm 1.2^{\mathrm{ab}}$ \\
Carp & $2813.7 \pm 926.3^{\mathrm{a}}$ & $59.1 \pm 7.1^{\mathrm{a}}$ & $1007.0 \pm 301.4^{\mathrm{a}}$ & $37.0 \pm 6.2^{\mathrm{a}}$ \\
Catfish & $1694.7 \pm 361.8^{\mathrm{b}}$ & $52.5 \pm 5.9^{\mathrm{a}}$ & $499.0 \pm 119.0^{\mathrm{b}}$ & $29.5 \pm 3.4^{\mathrm{b}}$ \\
\hline
\end{tabular}

Values are averages of the triplicate measurements \pm standard deviation. Values followed by the same letters in the same column do not present significant difference by Tukey's test $(\mathrm{P} \leq 0.05)$. $\mathrm{N}=6$ 
The variables total length, fillet's weight, and fillet yield showed similarities between averages and medians. For the total length, although without significant difference among the fresh catch, the presence of atypical values is verified.

The catfish species not only showed the lowest fillet weight $(499.0 \mathrm{~g})$ but also the lowest fillet yield (29.5\%) alongside with pacu (30.7\%). Other works in the literature reveal fillet yield from 25.2 to $36.6 \%$ for different species of fresh catch (LimA et al., 2012). The total usage depends, beside the efficiency of the machinery for filleting and manual skills of the operators, on the anatomical shape of the body, size and weight of head, viscera, fins, and skin (Lima et al., 2012; INTARAK et al., 2015).

Among the biometric variables, probably the fillet yield has been the most studied (RutTen et al., 2005; Lima et al., 2012; BRitto et al., 2014), since this value and other biometric properties present a weak correlation (RUTTEN et al., 2005; NAVARRO et al., 2009). Fillet yield is relevant for fish production and fresh fish industries, because unlike other slaughter animals, the skeletal muscle of fish (fillets) corresponds to greater edible portion (INTARAK et al., 2015).

Fillet yield is a ratio of fillet's weight and carcass weight, and it is a parameter of the proportion of the edible part (INTARAK et al., 2015). Filleting implies the removal of the fins, bones, and skin (BRITTO et al., 2014; INTARAK et al., 2015). In order to understand the relation of fillet's total weight, fillet's weight alone, total length, and fillet yield, these variables were subjected to linear regression. In Table 3 the values for Pearson correlation are found.

Table 3. Coefficient of correlation among the total weight, total length, fillet's weight, and productive usage of fillets

\begin{tabular}{lllc}
\hline Biometric parameters & Pacu & Carp & Catfish \\
\hline Total weight $(\mathrm{g}) \times$ Total length $(\mathrm{cm})$ & 0.989 & 0.939 & 0.476 \\
Total weight $(\mathrm{g}) \times$ Fillet's weight $(\mathrm{g})$ & 0.994 & 0.952 & 0.898 \\
Fillet's weight $(\mathrm{g}) \times$ Total length $(\mathrm{cm})$ & 0.983 & 0.851 & 0.686 \\
Total weight $(\mathrm{g}) \times$ Fillet yield $(\%)$ & 0.584 & -0.696 & -0.140 \\
Fillet's weight $(\mathrm{g}) \times$ Fillet yield $(\%)$ & 0.666 & -0.450 & 0.307 \\
Total length $(\mathrm{cm}) \times$ Fillet yield $(\%)$ & 0.566 & -0.768 & 0.570 \\
\hline
\end{tabular}

In accordance with other studies (KAUSE et al., 2007; BRITTO et al., 2014), all biometric values related to fillet yield showed a weak coefficient of correlation, regardless of species.

BRITTO and co-workers (2014), studying fresh catch viola (Loricariichthys anus), have found that the animals with greater weight presented lower fillet yield, and that this is likely linked to the reproductive period, which reduces fillet yield owing to the increase of the gonads. RASMUSSEN and OSTENFELD (2000) state that fillet yield may be associated with the size and species of the fresh catch. Among the species in this study, it is noteworthy that for the grass carp, these correlations were not only weak, but also negative.

RUTTEN and co-workers (2005) reported that prediction equations on fillet yield, based on body measures are not sufficiently accurate. The authors yet reported that the fillet's weight may be predicted with precision by measuring the fresh fish parameters. And similarly to these authors, in evaluating the outcomes corresponding to the coefficients among total length, total weight and fillet's weight, a high and positive relation is verified. In addition, the 
best equation of prediction relates the total weight to fillet's weight, since, for the three studied species, it presented the highest coefficient of Pearson's correlation.

\subsection{Discriminant variables for differentiation among the species}

Aiming to better fathom the differences among the fishes, canonical discriminant analysis was applied. Canonical discriminant functions are linear combinations of the original variables with the goal of defining those that make the maximum separation among groups (HAIr et al., 2009; GonZÁlEZ et al., 2011).

Being deemed indispensible for classification of nutritional/food products that are to be marketed, the multivariate techniques, discriminant analysis and canonical discriminant analysis have been employed to multivariate biologic datasets, indicating the parameters, which indeed are foremost in the separations of groups of interest (ARvANITOYANNIS et al., 2005).

Table 4 shows the significance for every variable in the discriminant canonical functions. These values show the distinct influence that each variable wields in the classification process. With $88 \%$ of total variation, explained by Function 1, the best discriminant variables among the species of fresh fishes were the biometric ones, represented by total weight, followed by total length, fillet yield and fillet's weight. TVB-N and $\mathrm{pH}$ presented the lowest discriminant effect.

Table 4. Discriminant and canonical analysis results

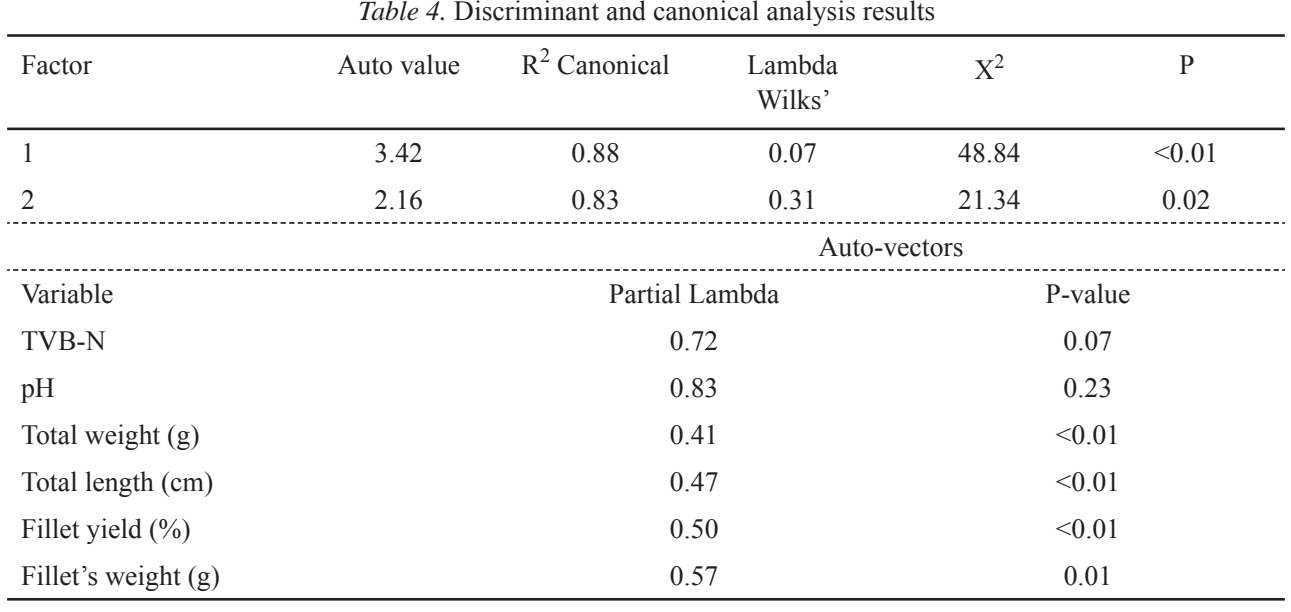

$\mathrm{X}^{2}$ : chi-square; $\mathrm{P}$ : significance

In the attempt to explain the discriminant power of the biometric variables, a relation with the descriptive data previously discussed was sought, and it was verified that the variables that mostly presented symmetry between average and median were the biometric ones. This symmetric relation indicates a normal distribution of the samples, one of the recommendations for the application of the discriminant analysis (GonZÁLEZ et al., 2011). As important as the symmetry between these two parameters is the presence of averages with significant differences among the fresh catch fishes, verified by the biometric values, which indicates variations among the species, and therefore, favouring the discrimination. 


\section{Conclusions}

The application of box plot as an evaluation instrument of freshness and biometric features of the studied three species of fresh catch eased the assessment of the variations among the species, and made quick and visual comparison of multiple variables possible. Besides, the comparisons among the descriptive statistics allowed for understanding the discriminative outcomes.

To Capes, for having provided the scholarship, to CNPq for financing the Project No. 456102/2014-0.

\section{References}

Arvanitoyannis, I.S., Tsitsika, E.V. \& Panagiotaki, P. (2005): Implementation of quality control methods (physicochemical, microbiological and sensory) in conjunction with multivariate analysis towards fish authenticity. Int. J. Food Sci. Tech., 40, 237-263.

BRASIL (1981): Ministry of Agriculture. Official analytical methods for the control of animal products and their ingredients. Brasília.

Briones-Labarca, V., Perez-Won, M., Zamarca, M., Aguilera-Radic, J.M. \& Tabilo-Munizaga, G. (2012): Effects of high hydrostatic pressure on microstructure, texture, colour and biochemical changes of red abalone (Haliotis rufecens) during cold storage time. Innov. Food Sci. Emerg., 13, 42-50.

Britto, A.C.P. De, Rocha, C.B., Tavares, R.A., Fernandes, J.M., Piedras, S.R.N. \& Pouey, J.L.O.F. (2014): Body yield and chemical composition of viola (Loricariichthys anus). Cienc. Anim. Bras, 15(1), 38-44.

FeiJoo, A.M.L.C. (2010): Medidas de tendência central (Measures of central tendency). -in: A pesquisa e a estatística na psicologia e na educação (Research and statistics in psychology and education). Centro Edelstein de Pesquisas Sociais, Rio de Janeiro, pp. 14-22.

Fernández-Segovia, I., Fuentes, A., Aliño, M., Masot, R., Alcañiz, M. \& Barat, J. M. (2012): Detection of frozenthawed salmon (Salmo salar) by a rapid low-cost method. J. Food Eng., 113(2), 210-216.

GonzÁlez, C., Liste, A. \& Felpeto, A. (2011): Tratamiento de datos con R, Statistics y SPSS. (Data processing with R, Statistics and SPSS) 1st ed., Ediciones Diaz de Santos, Spain.

Hair, J., Black, W., Babin, B., Anderson, R. \& Tatham, R. (2009): Multivariate data analysis, 6th ed., Bookman, Porto Alegre, 688 pages.

Huss, H.H. (1995): Quality and quality changes in fresh fish. FAO Fisheries Technical Paper, No: 348. Rome.

Intarak, I., Lhasudta, P., Jathurasitha, S., Wicke, M. \& Kreuzer, M. (2015): Effects of slaughter weight on carcass and meat characteristics of Punga fish (Pangasius bocourti Sauvage). Agric. Agric. Sci. Proc., 5, 164-169.

JABEen, F. \& ChAUDHRY, A.S. (2011): Chemical compositions and fatty acid profiles of three freshwater fish species. Food Chem., 125, 991-996.

Kause, A., Paananen, T., Ritola, O. \& Koskinen, H. (2007): Direct and indirect selection of visceral lipid weight, fillet weight, and fillet percentage in a rainbow trout breeding program. J. Anim. Sci., 85(12), 3218-3227.

Lem, S., Onghena, P., Verschaffel, L. \& VAn Dooren, W. (2013): The heuristic interpretation of box plots. Learn. Instr., 26, 22-35.

Lima, M.M., MujicA, C.P.I. \& LimA, M.A. (2012): Caracterização química e avaliação do rendimento em filés de caranha (Piaractus mesopotamicus). (Chemical characterization and evaluation of the yield of caranha fillets (Piaractus mesopotamicus)). Braz. J. Food Technol., 15, 41-46.

Mitterer-Daltoé, M.L., Carrillo, E., Queiroz, M I., Fiszman, S. \& Varela, P. (2013a): Structural equation modelling and word association as tools for a better understanding of low fish consumption. Food Res. Int., 52(1), 56-63.

Mitterer-Daltoé, M.L., Latorres, J.M., Treptow, R.O., Pastous-Madureira, L.S. \& Queiroz, M.I. (2013b): Acceptance of breaded fish (Engraulis anchoita) in school meals in extreme Southern Brazil. Acta Alimentaria, 42, 143-150.

Naes, V., Brockhoff, P. \& Tomic, O. (2010): Statistics for sensory and consumer science. John Wiley \& Sons, UK, 282 pages. 
Navarro, A., Zamorano, M.J., Hildebrandt, S., Ginés, R., Aguilera, C. \& Afonso, J.M. (2009): Estimates of heritabilities and genetic correlations for growth and carcass traits in gilthead seabream (Sparus auratus L.), under industrial conditions. Aquaculture, 289(3-4), 225-230.

Rasmussen, R.S. \& Ostenfeld, T.H. (2000): Effect of growth rate on quality traits and feed utilization of rainbow trout (Oncorhyncus mykiss) and brook trout (Salvelinus fontinalis). Aquaculture, 184, 327-337.

Rutten, M.J.M., Bovenhuis, H. \& Komen, H. (2005): Genetic parameters for fillet traits and body measurements in Nile tilapia (Oreochromis niloticus L.). Aquaculture, 246(1-4), 125-132.

Soares, L.S., Almeida, R.C.C., Cerqueira, E.S., Carvalho, J.S. \& Nunes, I.L. (2012): Knowledge, attitudes and practices in food safety and the presence of coagulase-positive staphylococci on hands of food handlers in the schools of Camaçari, Brazil. Food Control, 27(1), 206-213. 